Jurnal Pemberdayaan: Publikasi Hasil Pengabdian kepada Masyarakat

Vol. 2, No. 2, Agustus 2018, Hal. 275-282

ISSN: 2088 4559; e-ISSN: XXXX-XXXX

DOI:

\title{
IMPLEMENTASI POINT OF SALE (POS) UNTUK PENGELOLAAN KEUANGAN DI ARIZANAFOOD
}

\author{
Lisna Zahrotun ${ }^{1}$, Arfiani Nur Khusna ${ }^{2}$, Ika Arfiani ${ }^{3}$ \\ Universitas Ahmad Dahlan, Jl. Kapas No. 9 Semaki Yogyakarta ${ }^{123}$ \\ Email: lisna.zahrotun@tif.uad.ac.id
}

\begin{abstract}
ABSTRAK
Makanan merupakan komponen penting dari kehidupan manusia, ikan merupakan salah satu konsumsi makanan yang mempunyai protein dan kalsium tinggi. Masyarakat Sleman khususnya mengkonsumsi ikan tiap tahun terdapat peningkatan dan penurunan. Bisnis makanan khususnya olahan ikan merupakan bisnis unggulan yang menjanjikan untuk tahun mendatang. UKM Arizanafood mempunyai fokus pada usaha olahan ikan yaitu abon ikan tuna untuk anak-anak dan dewasa. UKM Arizanafood mempunyai kendala dan hambatan pada tahapan stok bahan baku yang terbatas, produksi yang terhambat dan tidak ada peningkatan, proses yang tidak didukung peralatan yang memadai, produk yang bersaing ketat di pasaran, manajemen keuangan akuntansi yang masih manual, distribusi produk belum terdapat alur yang jelas, pemasaran belum menerapkan teknologi berbasis website, sumber daya manusia belum dikelola dengan maksimal, sarana yang masih minim dan finansial dalam hal pelaporan belum dikelola dengan baik, sehingga untuk bersaing di pasar dunia akan sangat berat dihadapi. Pengembangan aplikasi berbasis teknologi internet yaitu aplikasi website dan mobile yang sedang berkembang dapat membantu memberikan solusi dari permasalahan yang dihadapi UKM Arizanafood dari sisi teknologi, sedangkan SCM (Supply Chain Management) untuk manajemen stok barang, CRM (Customer Relationship Management) untuk manajemen pelanggan, manajemen keuangan akuntansi meliputi keuangan kasir dan laporan laba rugi, manajemen kewirausahaan, manajemen strategik UKM, manajemen peningkatan mutu kualitas produk dan manajemen pengelolaan sumber daya manusia dapat membantu permasalahan dari sisi manajemen usaha yang dihadapi UKM Arizanafood.
\end{abstract}

Kata kunci : UKM, manajemen keuangan, promosi

\begin{abstract}
Food is an important component of human life, fish is one of the foods that have high protein and calcium. Sleman people especially consume fish every year there are increases and decreases. The food business, especially processed fish, is a promising business for the coming year. UKM Arizanafood has a focus on processed fish business, namely tuna abon for children and adults. Arizanafood UKM has constraints and obstacles at the stage of limited raw material stocks, hampered production and no improvement, processes that are not supported by adequate equipment, products that compete tightly in the market, financial accounting management that is still manual, product distribution has no flow Obviously, marketing has not implemented website-based technology, human resources have not been managed optimally, facilities that are still minimal and financial in terms of reporting have not been managed properly, so that competition in the world market will be very difficult. Internet technology-based application development, namely developing website and mobile applications can help provide solutions to problems faced by SMEs Arizanafood from the technology side, while SCM (Supply Chain Management) for goods stock management, CRM (Customer Relationship Management) for customer management, management financial accounting includes cashiers and income statement finances, entrepreneurial management, small and medium enterprises strategic management, management of product quality quality improvement and human resource management management can help problems from the business management side faced by Arizanafood.
\end{abstract}

Keywords : small and medium enterprises, accounting management, promotion 


\section{PENDAHULUAN}

Masyarakat kabupaten Sleman khususnya kecamatan Prambanan memiliki produksi ikan yang rendah dibanding kecamatan-kecamatan yang lain di wilayah kabupaten Sleman, berdasarkan data Badan Pusat Statistik Kabupaten Sleman yang dirilis tahun 2015, wilayah kecamatan Prambanan memiliki luas kolam 20,22 Ha, produksi 487.580 Kg dengan rata-rata produksi 24.110,17 Kg/Ha dan menduduki peringkat ke 15 dari 17 kecamatan yang ada di kabupaten Sleman sehingga dapat disimpulkan produksi ikan di wilayah kecamatan Prambanan sangat rendah, padahal kebutuhan masyarakat akan konsumsi ikan sangat tinggi. Saat ini pengusaha olahan ikan di wilayah kecamatan Prambanan masih mengambil ikan dari luar wilayah Prambanan terutama untuk ikan tuna, dengan mengambil dari luar daerah mengakibatkan harga jual ikan menjadi tinggi karena untuk mendapatkan ikan membutuhkan biaya yang besar.

\begin{tabular}{|c|c|c|c|}
\hline $\begin{array}{c}\text { Kecamatan } \\
\text { District }\end{array}$ & $\begin{array}{l}\text { Luas Kolam (Ha) } \\
\text { Total Area of Fishpond }\end{array}$ & $\begin{array}{l}\text { Produksi }(\mathrm{Kg}) \\
\text { Production }\end{array}$ & $\begin{array}{c}\text { Rata - rata Produksi }(\mathrm{Kg} / \mathrm{Ha}) \\
\text { Average Production }\end{array}$ \\
\hline 1. Moyudan & 30,81 & 994260 & 32268,60 \\
\hline 2. Minggir & 63,90 & 1996050 & 31236,60 \\
\hline 3. Seyegan & 79,02 & 4170760 & 52779,06 \\
\hline 4. Godean & 71,36 & 1940510 & 27193,25 \\
\hline 5. Gamping & 105,01 & 3962730 & 37736,69 \\
\hline 6. MIati & 95,37 & 3143220 & 32956,78 \\
\hline 7. Depok & 68,12 & 3080690 & 45226,45 \\
\hline 8. Berbah & 56,97 & 2363190 & 41478,39 \\
\hline 9. Prambanan & 20,22 & 487580 & 24110,17 \\
\hline 10. Kalasan & 101,65 & 3720910 & 36604,40 \\
\hline 11. Ngemplak & 119,26 & 5604480 & 46995,37 \\
\hline 12. $\mathrm{Ngaglik}$ & 10,86 & 249010 & 22933,32 \\
\hline 13. Sleman & 11,48 & 365880 & 31876,63 \\
\hline 14. Tempel & 18,34 & 610170 & 33278,97 \\
\hline 15. Turi & 38,61 & 1205200 & 31212,29 \\
\hline 16. Pakem & 20,33 & 429060 & 21106,85 \\
\hline 17. Cangkringan & 48,89 & 1856700 & 37980,20 \\
\hline Jumlah & 960,20 & 36180400 & 37680,07 \\
\hline
\end{tabular}

Gambar 1.Tabel statistik persentase konsumsi makanan di Kab. Sleman (sumber: BPS Kab. Sleman)

Berdasarkan data Badan Statistik kabupaten Sleman, masyarakat wilayah Sleman mengkonsumsi ikan sebesar 5,3\% untuk wilayah kota di Sleman dan 5,64\% untuk wilayah pedesaan di Sleman. Ikan tuna mempunyai kandungan nutrisi yang tinggi, diantaranya yaitu protein, karbohidrat, lemak dan vitamin. Kandungan yang lengkap pada ikan tuna menjadi keunggulan tersendiri. Ikan tuna banyak dicari oleh para pecinta ikan untuk dijadikan makanan olahan ikan tuna yang lezat, baik anak-anak maupun orang tua sangat baik mengkonsumsi ikan tuna. Manfaat ikan tuna bagi kesehatan yaitu dapat menghindari stroke, menurunkan tekanan darah tinggi, baik untuk jantung, mampu menjaga imunitas tubuh dan pencegahan kanker karena banyak mengandung vitamin B. Olahan ikan tuna bisa berupa abon, bakso, bakso tahu, otak-otak, empal, amplang dan kaki naga. 
Mitra Usaha Kecil Menengah (UKM) Arizanafood, terletak di wilayah Sleman, Daerah Istimewa Yogyakarta. Merupakan UKM yg berfokus pada produk abon ikan tuna, dilatarbelakangi kebutuhan olahan ikan tuna yang tinggi di masyarakat dan masih sedikitnya produsen olahan ikan tuna serta keprihatinan karena beredarnya makanan yang mengandung bahan-bahan tidak alami serta mengandung pengawet, yang tentu saja tidak baik jika dikonsumsi terus menerus.

Proses mencari stock bahan baku yaitu dengan memesan kepada pemasok (melalui sms sehari sebelum digunakan), agar diantar besok (pagi) untuk diolah. Seminggu minimal membutuhkan $5 \mathrm{~kg}-17 \mathrm{~kg}$ ikan tuna, setiap bulannya rata rata $30-40 \mathrm{~kg}$ ikan tuna. Untuk menjaga mutu bahan baku, hanya memesan bahan baku ketika akan langsung dibuat agar ikan benar2 segar, ketika ada ikan yang sudah kurang segar, maka dikembalikan dengan perjanjian awal (yaitu jika ada yg tidak bagus bahan baku boleh dikembalikan). Selama ini tidak pernah ambil di pemasok lain, jika bahan terbatas maka menunggu sampai pemasok siap karena jika mengambil di pemasok lain, bahan baku kurang bagus kualitasnya sehingga produksipun terganggu karena menunggu bahan baku.

Perencanaan produksi tiap bulannya belum ada, saat ini hanya produksi sesuai permintaan agen saja dengan sistem PO (Pre Order) dengan membuat list antrian pemesanan. Perhitungan keuangan dan akuntansi masih manual menggunakan buku biasa dan tidak tertib sehingga laba rugi produksi belum diketahui secara pasti. Pencatatan saat ini hanya ada buku produksi dan buku distribusi. Pemasaran juga belum mempunyai website sebagai toko online yang dapat diakses siapa saja sehingga saat ini konsumen masih terbatas dari pengguna instagram dan fanspage. Target konsumen produk yaitu para ibu yang mempunyai anak usia 1 tahun keatas.

\section{METODE}

Berdasarkan hasil observasi, wawancara dan diskusi dengan mitra, dapat disimpulkan bahwa permasalahan utama yang perlu diselesaikan, antara lain :
a. Perencanaan proses pengolahan abon ikan tuna.
b. Proses pengolahan abon ikan tuna.
c. Pemasaran produk abon ikan tuna.
d. Pengelolaan keuangan dan stok barang

Dalam pengabdian ini akan lebih ditekankan kepada pengelolaan/manajemen meliputi SCM (Supply Chain Management) untuk manajemen stok barang, CRM (Customer 
Relationship Management) untuk manajemen pelanggan, manajemen keuangan akuntansi, manajemen kewirausahaan, manajemen peningkatan mutu kualitas produk dan manajemen pengelolaan sumber daya manusia.

Tahapan dalam pengabdian ini meliputi :

1. Survey awal untuk identifikasi permasalahan UKM Arizana food dan warga sekitar di wilayah Trukan Sumberharjo Prambanan Sleman.

2. Melakukan identifikasi permasalahan yang dihadapi oleh UKM Arizana food di Dusun Trukan.

3. Melakukan sosialisasi dengan mitra UKM Arizana food untuk mendukung kegiatan pengabdian tersebut.

4. Menyusun prioritas permasalahan yang akan diselesaikan terlebih dahulu berdasarkan skala prioritas dari hasil diskusi dengan mitra.

5. Merancang jadwal kegiatan pelatihan manajemen perencanaan proses produksi dan membuat kesepakatan jadwal yang telah dibuat dengan mitra.

6. Memberikan pelatihan yang mendukung dalam proses pengolahan abon ikan tuna.

7. Memberikan pelatihan manajemen stok dan mengelola keuangan bagi mitra.

\section{HASIL, PEMBAHASAN, DAN DAMPAK}

Kegiatan pengabdian ini diawali dengan mengadakan Focus Group Discussion (FGD) mengenai manajemen keuangan dalam sebuah perusahaan yang dihadiri oleh pemilik usaha arizanafood. Dari kegiatan ini para pegawai khususnya pemilik usaha mempunyai wawasan tentang pengelolaan keuangan yang baik serta bagaimana pengelola keluar masuknya barang yang sesuai dengan prosedur perusahaan. Kegiatan yang lainnya berupa pelatihan aplikasi POS yang telah dibuat yang dapat dilhat pada Gambar 2. Kegiatan ini bertujuan untuk melatih pegawai yang mampu mengoperasikan computer untuk dapat bertindak sebagai kasir dalam melayani konsumen. Sehingga mereka bisa paham dalam menggunakan aplikasi kasir ini.

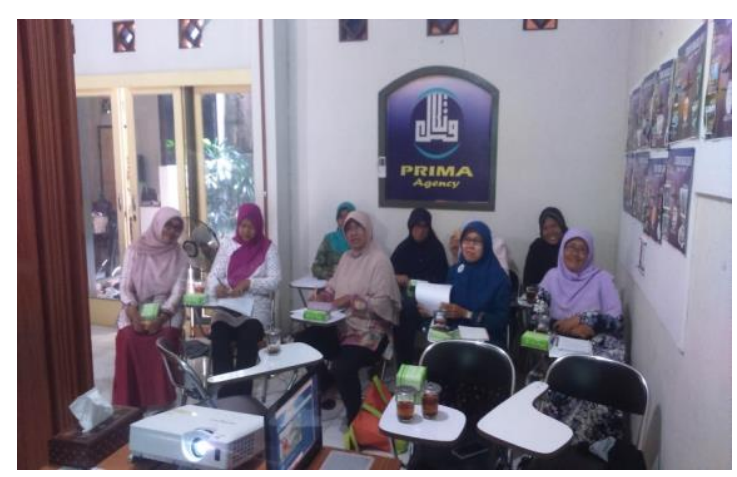

Gambar 2. Pelatihan Penggunaan Aplikasi POS 
Aplikasi POS ini diawali dengan form login seperti Gambar 3 untuk level user sebagai admin maupun kasir. Seluruh data akan dikelola oleh admin, sedangkan kasir hanya berhak melakukan transaksi penjualan barang kepada konsumen.

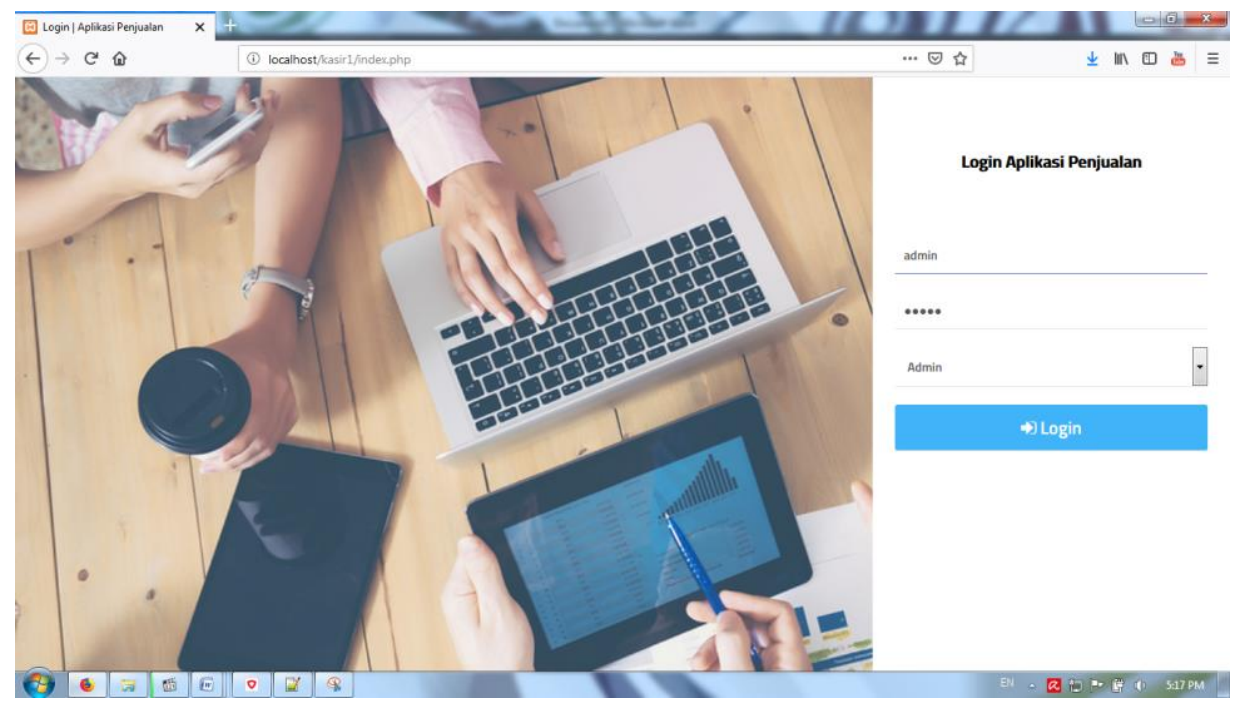

Gambar 3. Halaman menu login POS

Ketika admin berhasil login, maka selanjutnya akan muncul form dashboard untuk admin seperti Gambar 4 dalam menu ini admin dapat mengelola seluruh data yang ada.

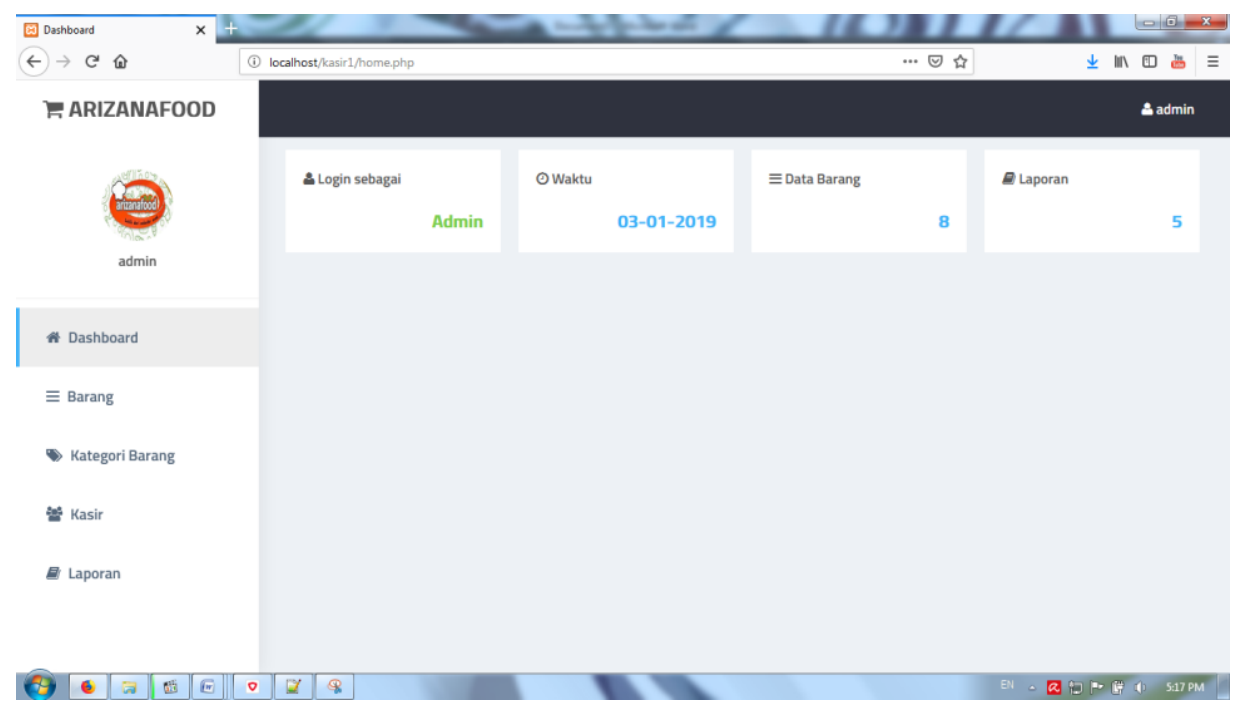

Gambar 4. Halaman menu utama admin

Apabila user yang login adalah kasir, maka akan ditampilkan form halaman kasir seperti Gambar 5, kasir diberikan hak akses untuk mengelola transaksi penjualan barang kepada konsumen. Hasil dari transaksi kasir ini nantinya dapat dicetak oleh admin dalam periode tertentu. 
2018 Jurnal Pemberdayaan: Publikasi Hasil Pengabdian kepada Masyarakat - ISSN: 2088 4559; e-ISSN:

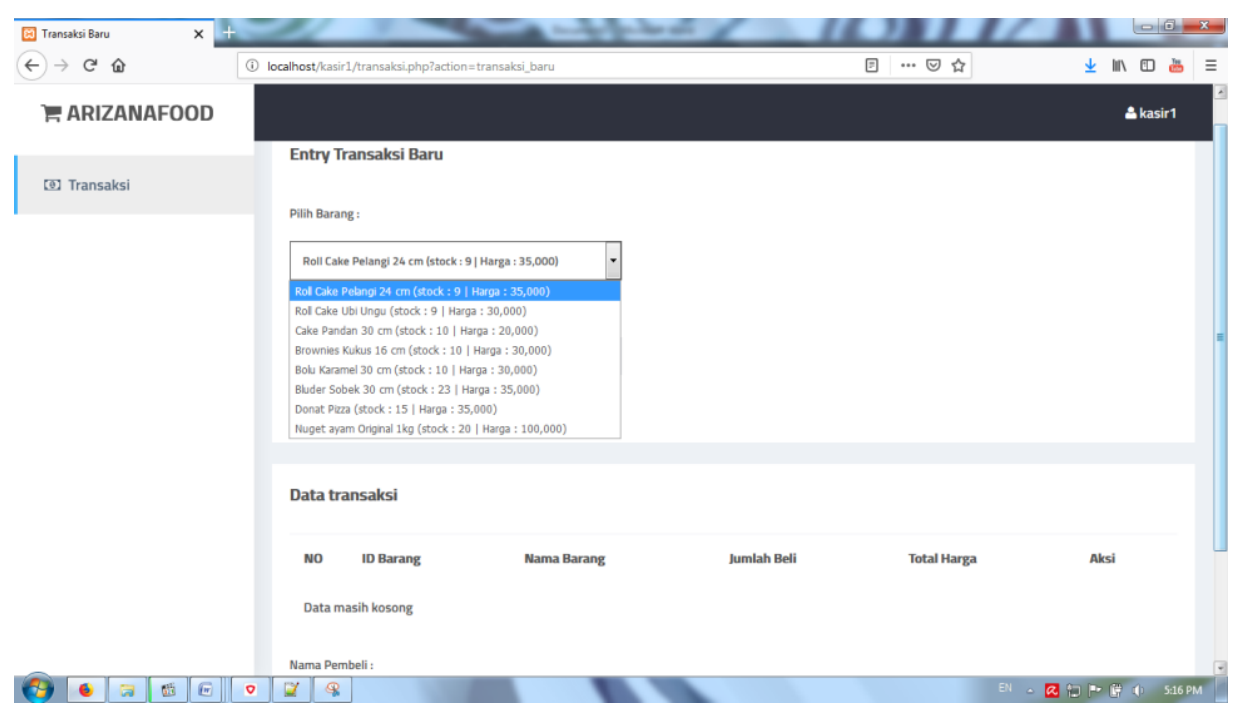

Gambar 5. Halaman menu utama kasir

Admin dapat mengupdate data barang yang ada melalui menu barang seperti Gambar 6, sedangkan untuk mengupdate kategori barang dapat dilakukan melalui menu kategori seperti Gambar 7.

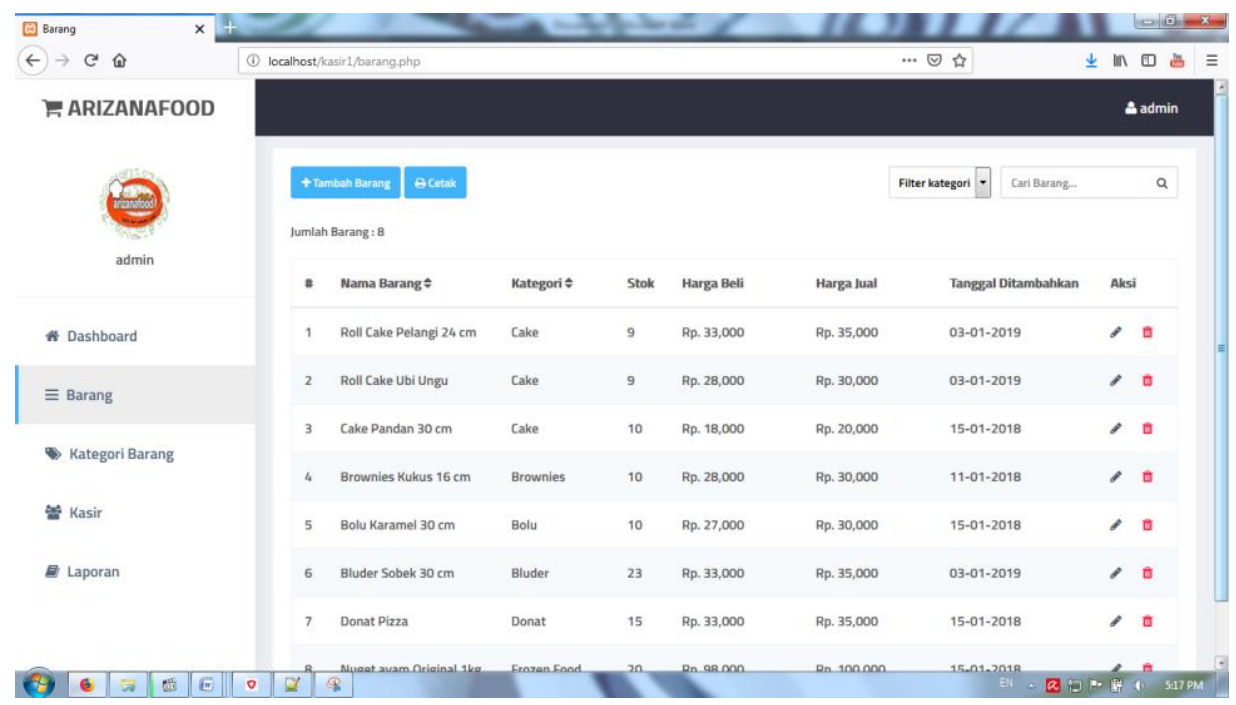

Gambar 6. Halaman menu daftar barang 


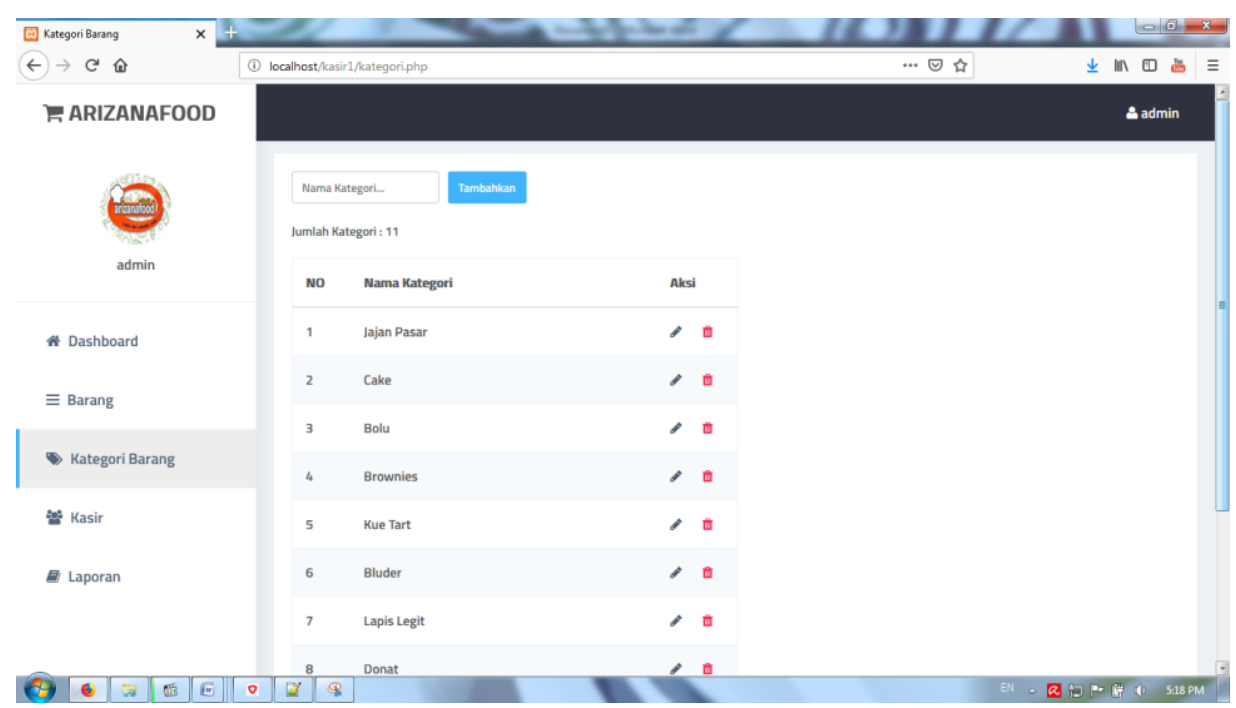

Gambar 7. Halaman menu kategori barang

Untuk mendapatkan info detail transaksi, admin dapat mencetak laporan secara periodic bulanan maupun harian seperti Gambar 8.

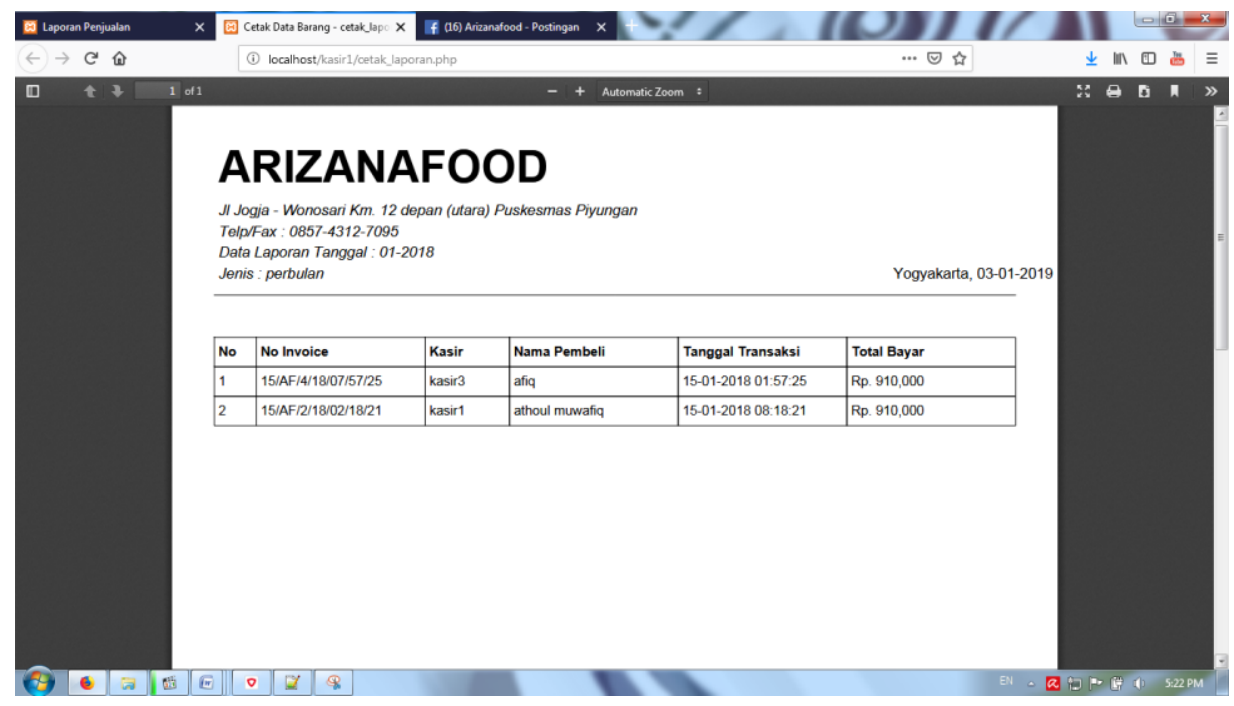

Gambar 8. Pencetakan laporan kasir

\section{SIMPULAN}

Telah dilakukan pengabdian kepada masyarakat di Arizanafood dengan membantu memberikan penyuluhan mengenai pengelolaan/manajemen keuangan serta pelatihan aplikasi POS kasir dan stok barang untuk pegawai di Arizanafood. Sehingga proses pengecekan stok barang dan proses transaksi jual beli barang di Arizanafood bisa lebih terkontrol dan terdokumentasi dengan lebih baik. 


\section{DAFTAR PUSTAKA}

Bidang integrasi pengolahan data statistik. 2015. Sleman Dalam Angka 2015. Bantul: BPS Provinsi DIY.

Bidang integrasi pengolahan data statistik. 2015. Indeks Pembangunan Manusia Kabupaten Sleman 2015. Bantul: BPS Provinsi DIY.

Nitisusastro Mulyadi. 2015. Kewirausahaan dan Manajemen Usaha kecil. Bandung: Alfabeta.

\section{UCAPAN TERIMAKASIH}

Terimakasih kepada Universitas Ahmad Dahlan atas bantuan pendanaan sehingga kegiatan pengabdian ini bisa terlaksana dengan lancar. 